\title{
Morphological identification and DNA barcoding of a new species of Parabrachiella (Siphonostomatoida: Lernaeopodidae) with aspects of their intraspecific variation
}

\author{
M.M. Montes ${ }^{\mathrm{a}, *}$, R. Castro-Romero ${ }^{\mathrm{b}}$, S.R. Martorelli ${ }^{\mathrm{a}}$

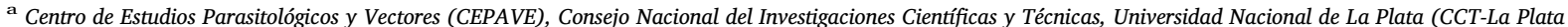 \\ CONICET-UNLP), Calle $120 \mathrm{~s} / \mathrm{n}$ e/60 y 64, 1900, La Plata, Buenos Aires, Argentina \\ b Universidad de Antofagasta, Facultad de Ciencias del Mar y recursos naturales, Departamento de Ciencias Acuáticas y Ambientales, Casilla 170, Antofagasta, Chile
}

\section{A R T I C L E I N F O}

\section{Keywords:}

Argentina

Brackish water

Symbiont copepod

Juvenile mullet

COI

\begin{abstract}
A B S T R A C T
We present a detailed morphological description and a DNA barcoding of Parabrachiella platensis $\mathrm{n}$. sp. collected from Mugil liza Valenciennes in Samborombon Bay (Buenos Aires, Argentina). This new species was compared with two Parabrachiella species parasitic on mugilids: Parabrachiella exilis (Shiino, 1956) and Parabrachiella mugilis (Kabata, Raibaut et Ben Hassine, 1971). Parabrachiella platensis n. sp. differs from those species in the shape of posterior processes, the anal slit with two pairs of bipartite papillae, the size of cephalothorax, the trunk, the maxilla, the microhabitat on the host, and the lack of caudal rami. On the host, the new species was in the nostrils (a new site for a species of the genus Parabrachiella) and in the fins base. Some minor morphological differences were observed in relation to the locations on the host. The molecular analysis conducted based on mtDNA-COI between specimens of the new species on the fins and nostrils showed a genetic similarity of $99.8 \%$. This percentage supports that the specimens found in nostrils and fins base could represent a single species. New studies on $P$. platensis n. sp., including infection of the same fish with the two forms, could bring some new information. Anyway according to the genetic information provided and the minimal morphological differences spotted we conclude that the two forms are a single specie. The differences observed are possibly influenced by the place of the host where the two forms of copepods were found, nostrils and fins. The new species was also molecularly compared to other five species of Parabrachiella including P. exilis (parasitizing mugilid from Chile), Parabrachiella anisotremis, Parabrachiella auriculata, Parabrachiella merluccii, and $P$. hugu (the last two sequences were taken from the GenBank). The genetic distance of $9 \%$ among P. platensis $\mathrm{n}$. sp. and $P$. exilis, which is the close morphological related species, allow to states that these two copepods on mugilids belong to different species and then validating the morphological differences found between them.
\end{abstract}

\section{Introduction}

The Lernaeopodidae is one of the most numerous families of copepods and its representatives are extensively adapted to parasitism. Most of the lernaeopodid species represents narrow host specificity and parasitize specific anatomical locations on their fish hosts (Piasecki et al., 2010). The genus Parabrachiella Wilson, 1915 is one of the most numerous genera in this species-rich family. According to Piasecki et al. (2010), the genus Parabrachiella contains 67 species. In Argentina, Etchegoin et al. (2006) redescribed Parabrachiella spinicephala Ringuelet, 1945, a parasite of the Brazilian sandperch, Pinguipes brasilianus Cuvier. In the same country, Sardella et al. (1995) and Alarcos and Etchegoin (2010) reported Parabrachiella chevreuxii (Van Beneden,
1891), parasitizing the whitemouth drummer, Micropogonias furnieri (Desmarest). Another congener-Parabrachiella insidiosa (Heller, 1865), was found by Sardella and Timi (1995) on Merluccius hubbsi Marini. Cantatore et al. (2012) provided a list of copepods parasites of fishes from the Argentine Sea and found Parabrachiella amphipacifica (Ho, 1982) infecting Cottunculus granulosus Karrer.

Mugilids (mullets) have been reported as hosts for many lernaopodid copepods. In Chile, Parabrachiella exilis (Shiino, 1956), was reported by Castro Romero and Baeza Kuroki (1986) on flathead grey mullet, Mugil cephalus Linnaeus. Knoff et al. (1994) reported P. exilis hosted by lebranche mullet, Mugil liza Valenciennes, from Brazil. Parabrachiella mugilis (Kabata, Raibaut et Ben Hassine, 1971) was reported parasitizing golden grey mullet Liza aurata (Risso), in the North Atlantic, the

\footnotetext{
* Corresponding author.

E-mail address: martinmiguelmontes@gmail.com (M.M. Montes).
} 
Mediterranean Sea, the Lake of Tunis (lagoon), and the Gulf of Oman at Muscat (Kabata et al., 1971).

During the nostrils and fins examinations in juvenile $M$. liza from Samborombón Bay, copepods of Parabrachiella sp. were found.

The aim of the study was to determine the taxonomic status of the specimens parasitic on $M$. liza and its relationships with $P$. exilis, which is also parasitic on mugilid, with other three fishes species collected in Antofagasta (Chile) waters, and with another two species from GenBank.

\section{Materials and methods}

\subsection{Specimens and taxonomy}

Fish samples were collected in the Ajó River $\left(36^{\circ} 20^{\prime} 12^{\prime \prime} \mathrm{S}\right.$, $56^{\circ} 54^{\prime} 17^{\prime \prime}$ ), Samborombón Bay, Buenos Aires province, Argentina, from 15 March through 21 September 2009. Fish were captured with a modified Garlito/Bituron stationary net (Colautti 1998) plus a trawl net $10 \mathrm{~m}$ long with a $5 \mathrm{~mm}$ stretched mesh in the wings and a $2.5 \mathrm{~mm}$ stretched mesh in the codend. Captured fish were fixed with $10 \%(\mathrm{v} / \mathrm{v})$ aqueous formalin, weighed, and measured. Some fish were carried to the laboratory alive and the parasites found were fixed for DNA extraction as we mention below. The fish specimens ranged from 3.64 to $23.4 \mathrm{~cm}$ in standard length and from approximately 1 to $400 \mathrm{~g}$ in weight. The nasal cavities were dissected under a stereomicroscope, and parasites detected were removed and stored in $10 \%$ buffered formalin. Parasite appendages were dissected, cleared in lactic acid, and examined under light microscopy. Drawings were made with the aid of a drawing tube. Measurements for females and males are given in $\mathrm{mm}$ as mean values followed by ranges in parentheses. Terminology follows Huys and Boxshall (1991), but detailed terminology related to body parts is based on Kabata (1979). Specimens fixed in formalin, were dehydrated in a series of increasing concentrations of ethanol, dried to the critical point in an EMITECH model K850, and sputtercoated with gold. Samples were then observed and photographed in a Philips SEM 505 microscope equipped with digital-imaging program (Soft Imaging System ADDA II [SIS]).

\subsection{Molecular data}

Copepod specimens, collected from the nostrils and the fins were preserved separately in $96 \%$ ethanol and kept at $-20{ }^{\circ} \mathrm{C}$ until DNA extraction. Specimens of four other Parabrachiella species from fishes of Chile were included in the analysis: Parabrachiella anisotremi (Castro Romero et Baeza Kuroki, 1989); Parabrachiella auriculata (Castro Romero et Baeza Kuroki, 1987), P. exilis, and Parabrachiella kabatai (Luque et Farfan, 1991). Sequences of Parabrachiella merluccii (BassettSmith, 1896) and Parabrachiella hugu (Yamaguti, 1939), deposited in Bold Systems Public Data Portal and in GenBank, respectively, were also included in the mtDNA-COI analysis (Table 1). The Chilean Parabrachiella specimens for DNA extraction came from the private collection of one of the authors (RCR). A COI sequence of Ergasilus von Nordmann, 1832 from the IBOL project: TREAR, was also included as outgroup.

For DNA extraction a sample of $2-3 \mathrm{~mm}^{3}$ of ethanol-preserved tissue, $5 \mathrm{ml}$ of insect Lysis Buffer, and $0.5 \mathrm{ml}$ of Proteinase $\mathrm{K}, 20 \mathrm{mg} / \mathrm{ml}$ were placed in each well of 96-well Eppendorf plate for DNA extraction. Genomic DNA was extracted according to the glass fibre (GF) protocol for DNA extraction using 96-well plates by Ivanova et al. (2006a,b). Amplification of the $5^{\prime}$ barcode region of COI was made using the HCO2198_t1 (Folmer et al. (1994) tailed) (CAGGAAACAGCTATGACTAAACTTCAGGGTGACCAAAAAATCA), and LCO1490_t1 (Folmer et al. (1994) tailed) (TGTAAAACGACGGCCAGTGGTCAACAAATCATAAAGATATTGG) primers. PCR reactions were performed in 96-well plates. The reaction master mix consisted of $625 \mu \mathrm{l}$ of $10 \%$ trehalose, $200 \mu \mathrm{l}$ water, $125 \mu \mathrm{l}$ of buffer, $62.5 \mu \mathrm{MgCl}_{2}(50 \mathrm{mM}), 6.25 \mu \mathrm{ldNTP}(10 \mathrm{mM}), 12.5 \mu \mathrm{l}$ of each primer $(10 \mu \mathrm{M})$, and $6 \mu \mathrm{l}$ Taq DNA polymerase ( $5 \mathrm{U} / \mathrm{ml})$. Each well contained $10.5 \mathrm{ml}$ mixture and $2 \mathrm{ml}$ genomic DNA. The PCR reaction profile was comprised of an initial step of $2 \mathrm{~min}$ at $95^{\circ} \mathrm{C}$ and 5 cycles of $94^{\circ} \mathrm{C}$ for $30 \mathrm{~s}$, annealing at $45^{\circ} \mathrm{C}$ for $40 \mathrm{~s}$, and extension at $72{ }^{\circ} \mathrm{C}$ for $1 \mathrm{~min}, 35$ cycles of $94^{\circ} \mathrm{C}$ for $30 \mathrm{~s}$, annealing at $51{ }^{\circ} \mathrm{C}$ for $40 \mathrm{~s}$, and extension at $72{ }^{\circ} \mathrm{C}$ for $1 \mathrm{~min}$, final extension at $72{ }^{\circ} \mathrm{C}$ for $10 \mathrm{~min}$. Amplicons were visualized on $2 \%$ agarose E-GelH 96-well system (Invitrogen). The PCR amplification products where placed in 96-wells plate containing $6.25 \mu \mathrm{l}$ of $10 \%$ trehalose and posted to the University of Guelph for DNA sequencing. The COI barcode sequence was obtained according with the protocol of Ivanova and Grainger (2006). The sequencing of Chilean fish specimens was carried out in Macrogen Inc. (Korea).

Sequences were edited by eye using the platform GENEIOUS 5.1.7. Barcode fragment alignments were assembled using MAFFT v.7 (Katoh and Standley, 2013). We checked the nucleotide alignment for the presence of pseudogenes in Geneiuos Pro, using the translated amino acid sequences based on the invertebrate mitochondrial genetic code. The best partitioning scheme and substitution model for each DNA partition was chosen under the Bayesian Information Criterion (BIC; Schwarz 1978) using the "greedy" search strategy in Partition Finder v. 1.1.1 (Lanfear et al., 2012). The barcode fragment dataset was partitioned into first-, second-, and third-codon positions with the appropriate nucleotide substitution model implemented for each codon position (TIM + G for the first and second (Posada 2003); and HKY + G for the third codon position (Hasegawa et al., 1985)). Ergasilus sp. was used as the outgroup for the COI data set.

The phylogenetic reconstruction was carried out using Bayesian Inference (BI) through MrBayes v. 3.2.1 (Ronquist et al., 2012). The phylogenetic trees were reconstructed using two parallel analyses of Metropolis-Coupled Markov Chain Monte Carlo (MCMC) for $20 \times 10^{6}$ generations each to estimate the posterior probability (PP) distribution. Topologies were sampled every 1000 generations. The first $25 \%$ of the sampled trees were discarded as 'burn in'.

All $P$. platensis n. sp. sequences, trace files (electrophenogram), primer sequences used, and the specimen data were deposited in the public project "Parasites of fish and Invertebrates from Argentina (Code $=$ TREAR) in the Barcode of Life Database (BOLD) (www. barcodinglife.org). All obtained sequences were also deposited in GenBank (Table 1). The holotype, the allotype, and the paratypes of the new species were deposited in the invertebrate collection of the Museo de La Plata, Argentina.

Family Lernaeopodidae Milne Edwards, 1840

Genus Parabrachiella Wilson C.B., 1915

Parabrachiella platensis $\mathrm{n}$. sp.

Type-host: Mugil liza (Mugiliformes: Mugilidae); local name 'lisa', English name "Lebranche mullet".

Type locality: Ajó River, south of Samborombón Bay, Argentina $\left(36^{\circ} 20^{\prime} \mathrm{S}, 56^{\circ} 54^{\prime} \mathrm{W}\right)$.

Attachment site: Nostrils (primary) and fins.

Prevalence: $49.30 \%$ (nostrils) and $17.61 \%$ (fins).

Mean intensity: 2.16 (nostrils) and 1.7 (fins).

Type material: Deposited in the invertebrate collection of the Museo de La Plata, Argentina. Holotype adult female: MLP-Cr 26948 and allotype adult male: MLP-Cr 26949. Four paratypes adult females with the male: MLP-Cr 26945-47 and MLP-Cr 26950

Etymology: The species name "platensis" refers to the name of the estuary of La Plata River where the parasite was found.

Description (Figs. 1-11)

Adult Female [Based on 20 ovigerous specimens.] Measurements in Table 2. Body typically lernaeopodid. Cephalothorax (Fig. 1A and B) subcylindrical, dorsal shield widening terminally, reinforced by more sclerotized cuticle, (Fig. 1C). Antennule (Figs. 1D and 3C) foursegmented with swollen basal segment, and short solus at boundary between third and fourth segment (Fig. 3C). Distal segment armature (Figs. 1D and 3C) with short process 3 , simple seta 6 , bifid seta 5 , and 
Table 1

Details of copepods parasites of marine fishes Chile used in this study.

\begin{tabular}{|c|c|c|c|c|c|c|c|}
\hline Copepod parasites species [Code & Host (Family) & & & A & $\mathrm{C}$ & G & $\mathrm{T}$ \\
\hline \multicolumn{8}{|l|}{ Poecilostomatoida } \\
\hline \multicolumn{8}{|l|}{ Ergasilidae } \\
\hline Ergasilus sp. [Erg] & Mugil liza Valenciennes, 1836 (Mugilidae) & KU557411 & 678 & 172 & 118 & 141 & 247 \\
\hline \multicolumn{8}{|l|}{ Siphonostomatoida } \\
\hline \multicolumn{8}{|l|}{ Lernaeopodidae } \\
\hline Parabrachiella hugu (Yamaguti, 1939) & "Spheroides rubripes" = Takifugu rubripes & КT030285 & 558 & 163 & 68 & 100 & 227 \\
\hline Parabrachiella merlucci (Bassett-Smith, 1896) & Merluccius merluccius (Linnaeus, 1758) & KT208689 & 667 & 205 & 88 & 105 & 269 \\
\hline \multirow[t]{4}{*}{ Parabrachiella anisotremi (Castro Romero \& Baeza Kuroki, 1989) } & Anisotremus scapularis Tschudi,1846 (Pomadasidae) & KX815887 & 597 & 186 & 78 & 90 & 243 \\
\hline & & KX815888 & 615 & 193 & 77 & 96 & 249 \\
\hline & & KX815889 & 639 & 202 & 80 & 95 & 262 \\
\hline & & KX815890 & 651 & 204 & 83 & 97 & 267 \\
\hline \multirow[t]{3}{*}{ Parabrachiella auriculata (Castro Romero \& Baeza Kuroki, 1987) } & Cilus gilberti Abbott, 1899 (Sciaenidae) & KX815906 & 603 & 191 & 79 & 95 & 238 \\
\hline & & KX815907 & 630 & 197 & 84 & 102 & 247 \\
\hline & & KX815908 & 654 & 209 & 86 & 102 & 257 \\
\hline Parabrachiella exilis (Shiino, 1956) & Mugil cephalus Linnaeus, 1758 & KY026072 & 609 & 194 & 78 & 96 & 241 \\
\hline \multirow[t]{2}{*}{ sensu Castro-Romero \& Baeza-Kuroki 1986} & & KY026073 & 681 & 218 & 90 & 109 & 264 \\
\hline & & KY026074 & 699 & 220 & 93 & 110 & 276 \\
\hline sensu Knoff et al. (1986) & Mugil liza Valenciennes, 1836 (Mugilidae) & & & & & & \\
\hline sensu Shiino (1956) & "Kyphosus lembus" = Kyphosus vaigiensis (Quoy et Gaimard, 1825) & & & & & & \\
\hline \multirow[t]{4}{*}{ Parabrachiella kabatai (Luque \& Farfan, 1991) } & Isacia conceptionis (Cuvier, 1831) & KY026075 & 666 & 200 & 74 & 289 & 103 \\
\hline & & KY026076 & 666 & 199 & 75 & 104 & 288 \\
\hline & & KY026077 & 666 & 199 & 75 & 104 & 288 \\
\hline & & KY026078 & 627 & 193 & 67 & 94 & 273 \\
\hline \multirow[t]{4}{*}{ Parabrachiella platensis n. sp. (nostrils) } & Mugil liza Valenciennes, 1836 (Mugilidae) & KY026080 & 666 & 211 & 78 & 100 & 277 \\
\hline & & KY026081 & 666 & 210 & 79 & 101 & 276 \\
\hline & & KY026082 & 666 & 210 & 78 & 101 & 277 \\
\hline & & KY026083 & 660 & 207 & 77 & 101 & 275 \\
\hline \multirow[t]{2}{*}{ Parabrachiella platensis n. sp. (fins) } & Mugil liza Valenciennes, 1836 (Mugilidae) & KY026084 & 666 & 210 & 78 & 101 & 277 \\
\hline & & KY026085 & 666 & 210 & 78 & 101 & 277 \\
\hline
\end{tabular}

seta 4 plus short process 1 (not forming gibber). Antenna (Figs. 2A and B, 3D ) biramous, sympod-exopod long axis, exopod globose with short distal seta and another distolaterally margin (Fig. 3D). Endopod twosegmented. Apical armature (Figs. 2B, 3D) with robust curved hook 1, slender seta 2 , and seta 5 , process 4 on lateral side, and ventrally to the latter a pad of scale-like denticles on ventral margin. Labrum and labium forming buccal cone (Fig. 3E). Labrum bearing rostral seta ventrally (Fig. 2C), and fine setules. Labium margin with rows of dense setae, without sensilla on disto-ventral surface (Fig. 3E) or with two sensilla (one on each side) near distal margin (Fig. 3F) (only observed in the SEM). Mandible (Fig. 2D) with coxa globose, short; gnathobase blade with 3 secondary teeth. Dental formula: P1, S1, P1, S1, P1, S1, B4. Last secondary tooth smallest. Maxilla (Fig. 1A and B) medium size, arms separated, not fused (partially fused, in some specimens), with short nipple-like structure near base (Figs. 1A and B, 3A). Bulla short (Fig. 2G) with manubrium and expanded anchor (Fig. 2H). Maxillule (Figs. 2E, 3E and F) bilobate, inner lobe with two long setae of unequal length (differences in length shown in Fig. $3 \mathrm{E}$ and F), outer lobe with one (in copepods from fins) or two short setae of unequal length (in Fig. 3F only one seta visible). Maxilliped (Fig. 2F) subchelate. Corpus robust, no armature on myxal area. Claw (Figs. 2I, 4B and C ) slightly curved, barb stout, shaft with denticulate disto-ventral margin. A row with at least 5 denticles (commonly 5 ) on surface of claw near its base (Fig. 4B), at each side (not observed with optic microscopy) and two denticles on lateral surface close to the base in in copepods located on fins (Fig. 4B).

Trunk (Fig. 1A and B), with two pairs of short, blunt posterior (lateral) processes, dorsal anal region encircled by single pair of short papillae on each side (not visible with optic microscopy) with short ventral lobes bearing oviduct-orifice (Fig. 3A and B). Very short ventral genital process (Fig. 3B). Anal area with three short tubercles in specimens attached to fins (Fig. 4C). Egg sacs with 30-60 eggs (Fig. 1A).

Adult Male [Based on 20 specimens.] Measurements in Table 2. Body male type A (Fig. 5A) according to Kabata (1979). Cephalothorax about $40 \%$ trunk length. Antennule three segmented (Figs. 5B, 6A-C ). Basal segment longest and second and third segments approximately same length. Distal segment armed with elements 1, 2, 3, 4, 5, and 6 (Fig. 6C). Solus present (Fig. 6B) between second and third segment (not detected with optic microscopy). Whip not detected. Antenna (Figs. 5C, 6A and D) biramous, elongate, and prehensile. Sympod

Table 2

Measurements of Parabrachiella platensis n. sp. from the nostrils and fins.

\begin{tabular}{|c|c|c|c|}
\hline & Measurements & P. nasalis $\mathrm{n}$. sp. from nostrils & P. nasalis $\mathrm{n}$. sp. from fins \\
\hline \multirow[t]{8}{*}{ FEMALES } & Body long & $3.19(2.59-3.97)$ & $2.18(1.24-3.32)$ \\
\hline & Cephalothorax long by wide & $1.98(1.65-2.51)$ by $0.33(0.28-0.36)$ & $1.25(0.73-1.97)$ by $0.370 .30-0.46)$ \\
\hline & Maxila long by wide & $0.72(0.57-0.84)$ by $0.28(0.22-0.38)$ & $0.49(0.46-0.62)$ by $0.24(0.18-0.33)$ \\
\hline & Bulla long & $0.28(0.22-0.38)$ & \\
\hline & Trunk long by wide & $1.21(0.94-1.46)$ by $0.92(0.78-1.27)$ & $0.93(0.51-1.35)$ by $0.70(0.26-1.08)$ \\
\hline & Trunk lateral processes & $0.23(0.19-0.34)$ by $0.13(0.11-0.2)$ & $0.13(0.11-0.15)$ by $0.09(0.07-0.13)$ \\
\hline & Trunk Ventral lobes bearing oviduct, long by wide & $0.11(0.09-0.14)$ by $0.07(0.04-0.08)$ & \\
\hline & Egg Sac long by diameter & $1.27(1.13-1.46)$ by $0.41(0.32-0.54)$ & $1.22(0.72-1.76)$ by $0.44(0.40-0.51)$ \\
\hline \multirow[t]{3}{*}{ MALES } & Body long & $0.61(0.54-0.68)$ & $0.67(0.59-0.77)$ \\
\hline & Cephalothorax long by wide & $0.26(0.24-0.28)$ by $0.27(0.23-0.32)$ & $0.27(0.26-0.30)$ by $0.18(0.14-0.21)$ \\
\hline & Trunk long by wide & $0.35(0.31-0.40)$ by $0.28(0.18-0.38)$ & $0.39(0.34-0.47)$ by $0.16(0.15-0.77)$ \\
\hline
\end{tabular}



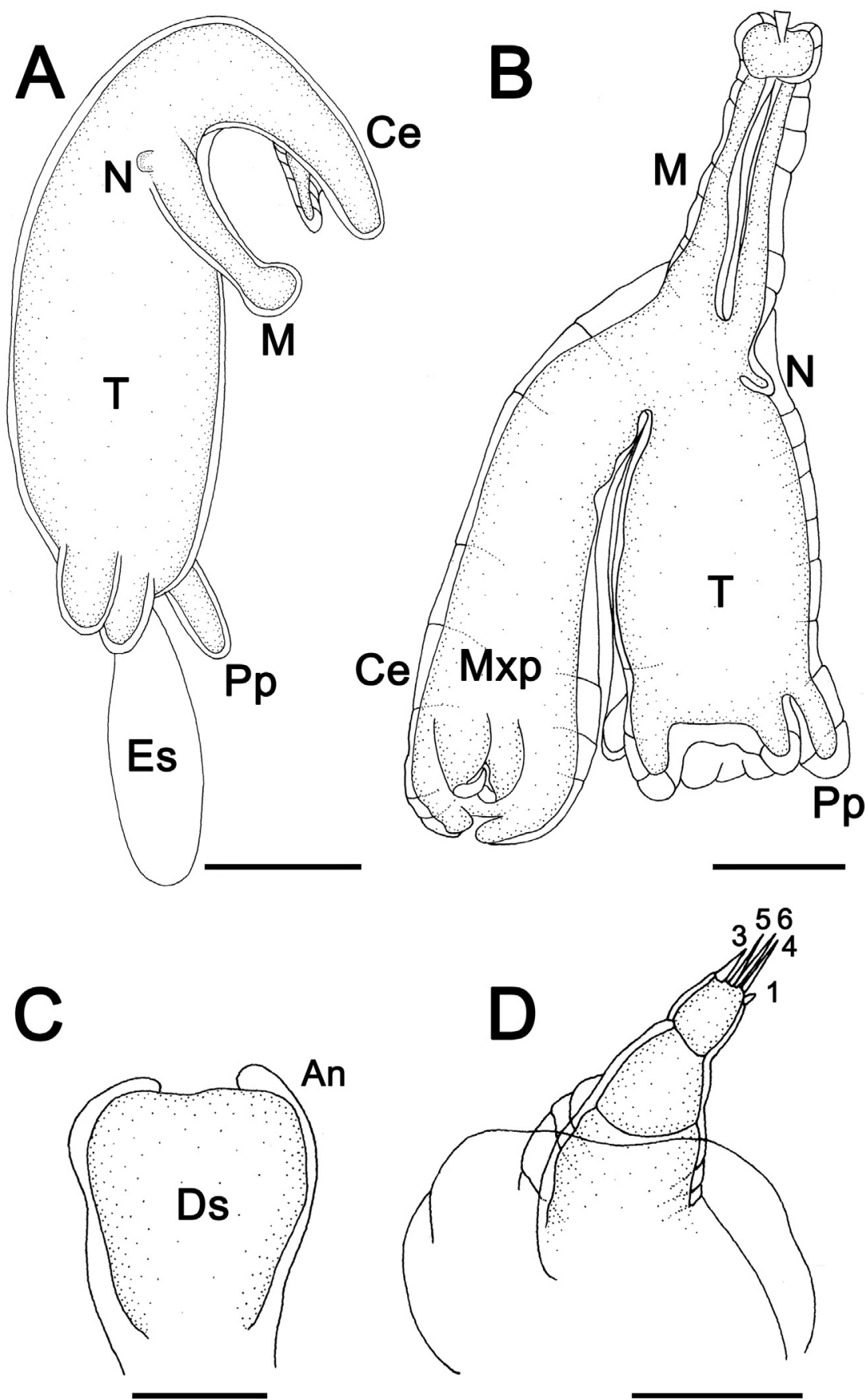

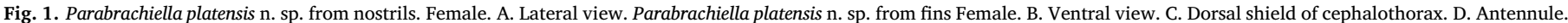

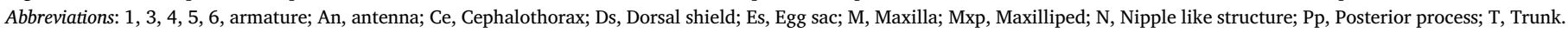
Scale bars: A, $500 \mu \mathrm{m}$; B, $250 \mu \mathrm{m}$; C, $150 \mu \mathrm{m} ; \mathrm{D}, 5 \mu \mathrm{m}$.

cylindrical, unarmed. Exopod bulbous, one-segmented, with two short spines on dorsal surface (in nostrils specimens). Endopod, two segmented, longer than exopod. Terminal segment with hook 1, seta 2, process 4 on outer surface, and seta 5 on ventral margin; ventral surface of distal segment with pad of denticles. Buccal cone (Fig. 6A and D) formed by labrum and labium. Labrum armed distally with setiform process, labium without sensilla. Mandible (Fig. 5F) blade with at least three teeth;. Maxillule (Fig. 6A and D) bilobate; inner lobe with 2 large, unequal subcylindrical setae and outer lobe with minute seta in ventral position (Fig. 6D). Maxilla (Figs. 5D, 6A) with basal segment of length slightly greater than width, subchela strongly curved distally. Maxilliped (Figs. 5E, 6E) with robust corpus without armature; subchela with robust base, nearly cylindrical, tapering at apex. Claw strongly curved.

Trunk with long axis of genital trunk slightly curved ventrally (Fig. 5A). Two distal genital lobes (Fig. 5G).

Parabrachiella exilis Shiino,1956

Type-host: Mugil cephalus (Mugiliformes: Mugilidae); local name "lisa", English name "grey mullet".

Type locality: Antofagasta, Chile.

Attachment site: fins.

Prevalence: $17.61 \%$ (fins).

Mean intensity: 1.

Adult Female [Based on 5 ovigerous specimens. Only a small number of details have been added concerning trunk posterior margin processes, which have been revealed via SEM.] 


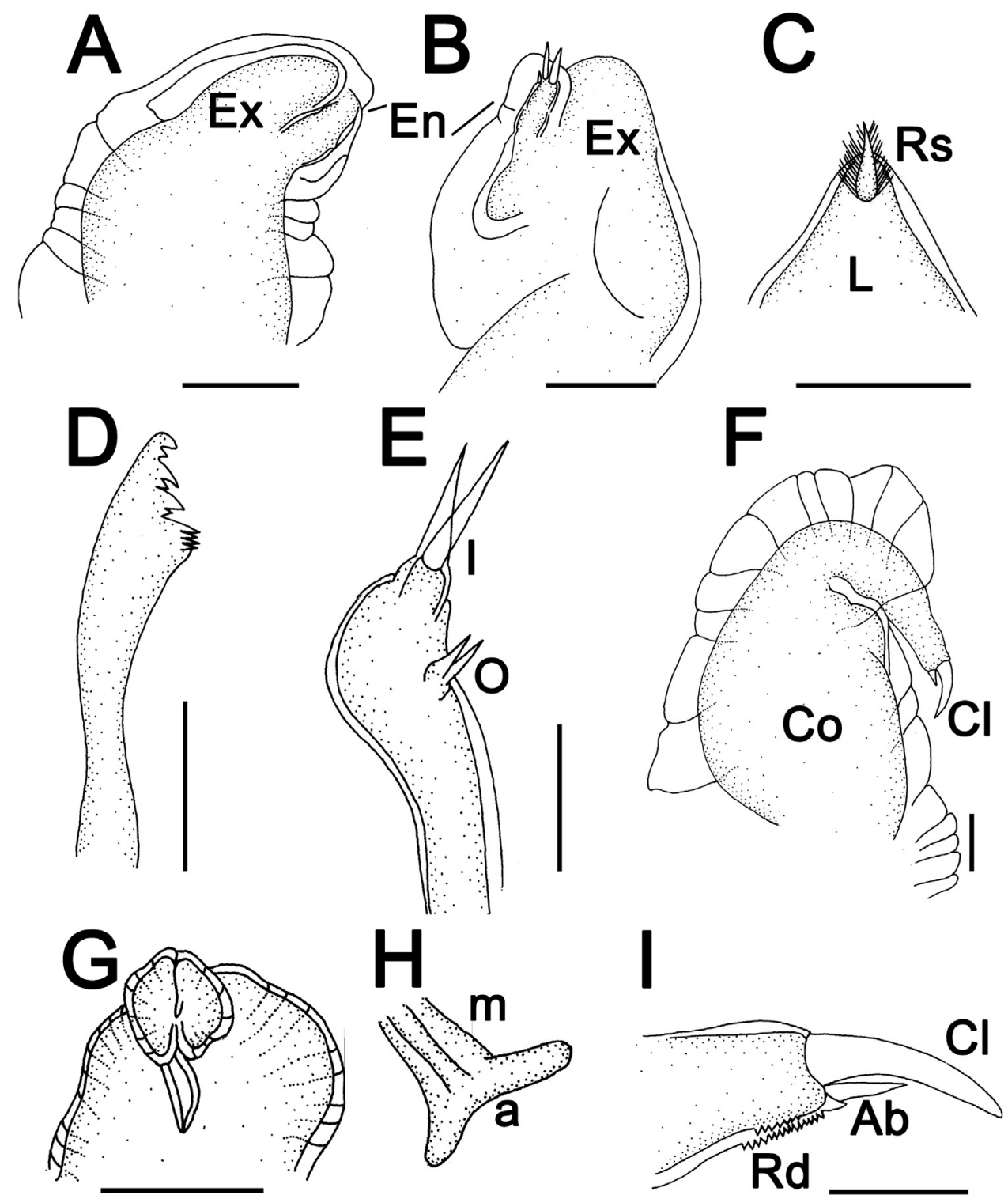

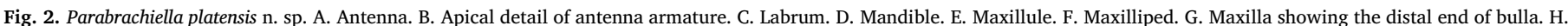

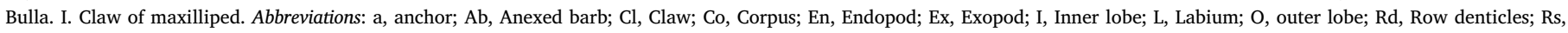
Rostral setules. Scale bars: A and B, $5 \mu \mathrm{m}$; C, $10 \mu \mathrm{m}$; D, $25 \mu \mathrm{m}$; E, $10 \mu \mathrm{m}$; F, $50 \mu \mathrm{m}$; G, $250 \mu \mathrm{m}$; H, $100 \mu \mathrm{m}$ : I, $25 \mu \mathrm{m}$.

Female trunk subrectangular with two pairs of posterior, blunt, processes and a short, dorsal, caudal rami (Fig. 7A and B).

\subsection{Molecular results}

The content of adenine, guanine, cytosine, and thymine for Parabrachiella species is listed in Table 1 . The six specimens of $P$. platensis $\mathrm{n}$. sp. analysed (four from the nostrils and two from the fins) showed a close distance with a similarity of $99.8 \%$, with sequences differing only by 1 or $2 \mathrm{bp}$.

The genetic distance was only $0.2-0.4 \%$ among the specimens collected in fins and nostrils Table 4 . This result confirmed that both sets parasitizing different habitats on the host would belong to the unique species showing minimal morphological differences.

The interspecific genetic distance (Table 3) among $P$. exilis and $P$. platensis $\mathrm{n}$. sp. is $9 \%$, both forming a clade more apomorphic than the others species studied (Fig. 8). Parabrachiella platensis showed a $16 \%$ of genetic distance from $P$. auriculata, $12 \%$ from both $P$. anisotremi and $P$. kabatai, and $14 \%$ from also both $P$. merluccii and $P$. hugu.

It is notorious the position of $P$. hugu, which is located more basal han all other species treated (Fig. 8), presenting a genetic distance of $14-18 \%$ from the other species used in this study (Table 3 ).

\section{Discussion}

Most of the 138 copepods specimens acquired from the host were dissected from the nostrils and only few specimens were collected from the fins. For this reason, we assumed that the preferable location of the new species is the nostrils. Parabrachiella specimens collected from fins showed several minor morphological differences with respect to those located in the nostrils. Parabrachiella platensis n. sp. residing within the nostrils has a pair of small papillae on each side of the anal slit; while the specimens from the fins have three tubercles in that region. Also, near the distal margin of the labium, the fins specimens have a pair of seta that are absent in P. platensis n. sp. located on the nostrils. Detailed examination of the maxilliped with SEM reveals that $P$. platensis n. sp. from nostrils has an external armature with two groups of at least 5 denticles each at the base of the claw, whereas the specimens from fins have only two denticles. The maxillule also provides other differences; $P$. platensis $\mathrm{n}$. sp. copepods from nostrils bears two setae on the outer 

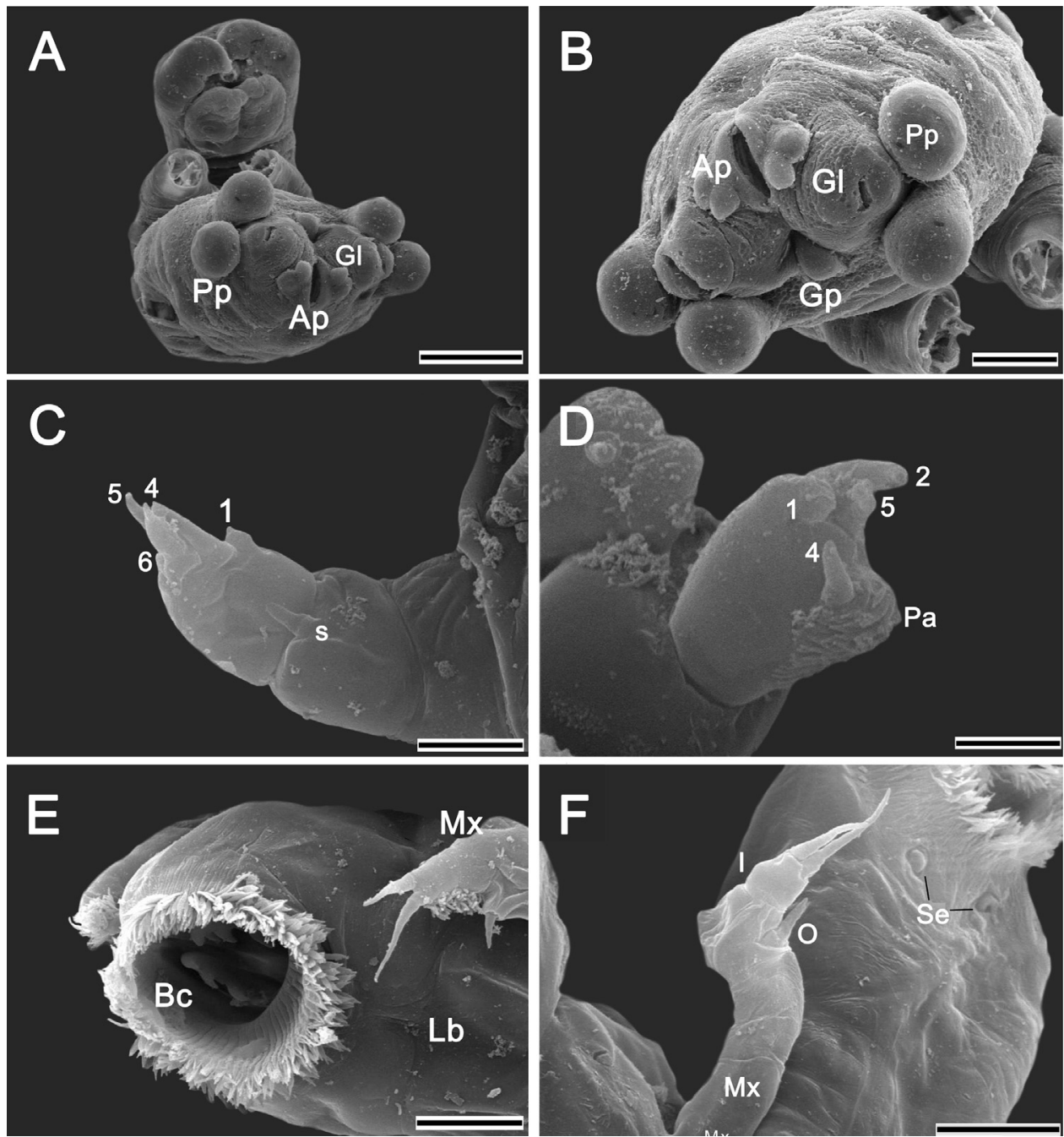

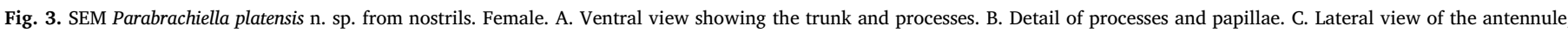

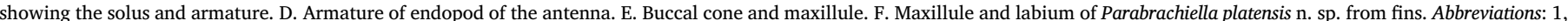

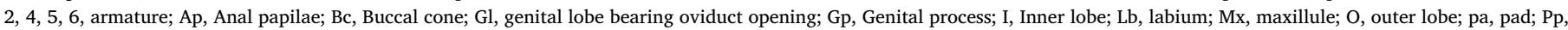
posterior processes; S, solus; Se, sensilia. Scale bar: A, $200 \mu \mathrm{m}$; B, $100 \mu \mathrm{m} ; \mathrm{C}, 10 \mu \mathrm{m}$; D, $5 \mu \mathrm{m}$; E, $20 \mu \mathrm{m}, \mathrm{F}, 20 \mu \mathrm{m}$.

lobe while fin specimens present only one seta. Finally, the antennules of $P$. platensis n. sp. from nostrils have a well-developed solus which is not observed in the specimens from the fins.

Together, the low intraspecific genetic distance between the specimens collected from the fin and nostrils $(0.2-0.4 \%)$ and the close morphological similarity between the two morphotypes, do not support the description as two separate species. This, differences agree with those presented by Costa et al. (2007) and Hill et al. (2001) who reported a distance of $0.5-0.8 \%$ among three geographic separate populations of crustaceans Calanus helgolandicus Claus, 1863. Despite of that, Burns et al. (2007) using COI sequences noticed that some valid butterfly species differ "only by one to three nucleotides". New studies on $P$. platensis n. sp., including infection of the same fish with the two forms, could bring some new information. Anyway according to the genetic information provided and the minimal morphological differences spotted we conclude that the two forms are a single specie. The differences observed are possibly influenced by the place of the host where the two forms of copepods were found, nostrils and fins.

Parabrachiella includes at least 67 species (Piasecki et al., 2010) of which 35 hold two pairs of posterior processes on the trunk (Castro Romero and Baeza Kuroki, 1987; Piasecki et al., 2010). The parasitic specimens examined from the host M. liza in Argentina during the present study were compared with this last group of species. Close examination led to the conclusion that the now described specimens are not conspecific with any of the above species. The difference between the new species and those described for mugilids are the size and shape of the posterior processes, the length of maxilla, the shape of the maxillary arm, the shape and relative size of the trunk and finally, it's appendages.

A comparison was made between the newly described specimens parasitizing M. liza, with two species of copepods infecting Mugilidae fishes: $P$. exilis and $P$. mugilis

The females of $P$. platensis $\mathrm{n}$. sp. are smaller than the specimens of $P$. exilis found by Knoff et al. (1994), but similar in size to those examined by Shiino (1956) and Castro-Romero and Baez-Kuroki (1986). Other differences between $P$. platensis n. sp. and the $P$. exilis specimen lie in the sizes of the cephalothorax (1.98 vs. 2.48 long), the second maxilla ( 0.72 vs. 1.28 long), the egg sac (1.27 vs. 2.14 long), and the trunk (1.21 vs. 1.62 long). Furthermore, the specimens described by Shiino (1956) had a longer trunk (1.69 long). Parabrachiella platensis n. sp. differs from $P$. exilis in the shape of the posterior processes-which are short and obtuse in P. platensis $\mathrm{n}$. $\mathrm{sp}$. vs. subconical in $P$. exilis (sensu Shiino, 1956). In addition, the small digitiform processes, (i.e., caudal rami), dorsally located occurring in P. exilis, (Fig. 7, and Fig. 19A and C of Shiino, 1956) are not present in the new species. Parabrachiella platensis n. sp. compared with $P$. exilis has short oviduct-orifice processes (similar in size to the posterior processes), two pairs of small bipartite papillae laterally flanking the anal slit (in nostrils specimens), 

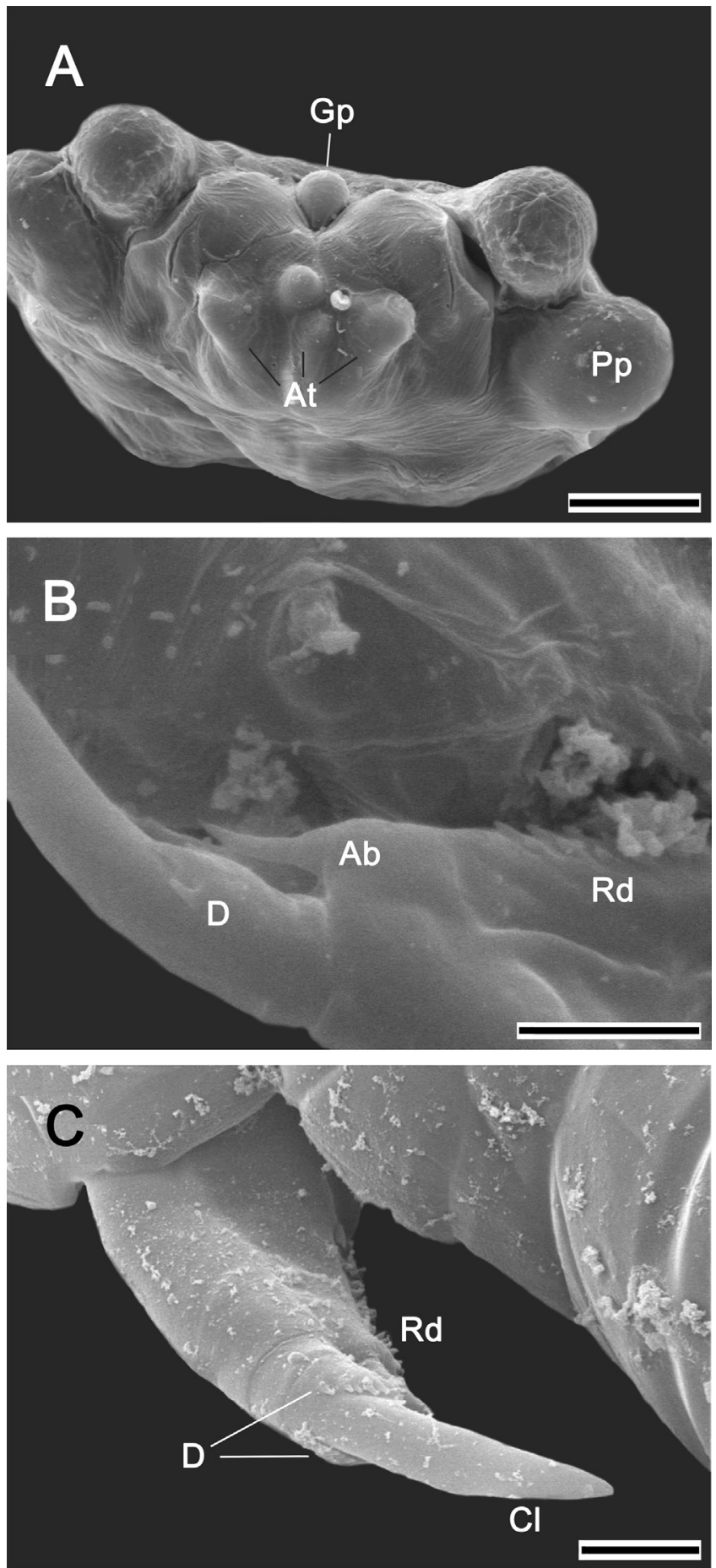

Fig. 4. Parabrachiella platensis n. sp. A. Posterior view of the Parabrachiella platensis n. sp. from fins. B. Armature claw maxilliped. A. Claw of maxilliped of the Parabrachiella platensis n. sp. from fins. Abbreviations: At, anal tubercles; Ab, Anexed barb; Cl, Claw; D, denticles; Gp, Genital process; Pp, Posterior process; Rd, Row of denticles. Scale bars: A, $100 \mu \mathrm{m} ; \mathrm{B}, 20 \mu \mathrm{m} ; \mathrm{C}, 10 \mu \mathrm{m}$.

and lack of caudal rami. The pairs of bipartite papillae flanking the anal slit has not been previously reported in other Parabrachiella species.

The comparison of $P$. mugilis parasitic on $L$. aurata and leaping mullet, Liza saliens (Risso), from Tunis (Kabata et al., 1971) with the described specimen likewise indicates that the two copepods are different species. Parabrachiella mugilis has a single pair of posterior processes (caudal rami) at the end of the trunk along with a short genital process, while $P$. platensis $\mathrm{n}$. sp. has two posterior processes on the trunk, in addition to small papillae around the anal slit lacking caudal rami. Furthermore, the species occupy different microhabitats on the host: $P$. mugilis lives attached to the fins, while $P$. platensis $\mathrm{n}$. $\mathrm{sp}$. were found either on inside the nasal cavity (a new site for a species of the genus Parabrachiella), or attached to the fins base. In this case, the females compared have a longer trunk (1.31 vs. 1.21 long), a smaller cephalothorax (1.56 vs. 1.98 long), and bigger maxilla (1.5 vs. 0.72 long). The male of $P$. mugilis is smaller than the male of $P$. platensis $\mathrm{n} . \mathrm{sp}$. ( 0.33 vs. 0.61 long).

The morphology per se indicates that Parabrachiella parasitizing mugilids ( $P$. exilis, $P$. mugilis and $P$. platensis $\mathrm{n}$. sp.) are different species.

According to the description presented in this paper, it is clear that the Parabrachiella species that parasitize South American mugilids represent a close related species, at least in the case of species that parasitize $M$. liza from Argentina and $M$. cephalus from Chile. Similarities between these copepod species make difficult to distinguish between them, but a high-resolution analysis of the posterior margin of the trunk has revealed significant differences in the anal region.

The genital area, which includes processes and lobes associated with the oviducts orifices, exhibit different shapes and degrees of development, which depend on the age or sexual maturity of the female specimen, for this, we must work only with adult gravid females. The anal area can also show morphological variation concerning associated projections, which are often species-specific. These anal tubercles are typically not considered caudal rami. Parabrachiella exilis bears the caudal rami located dorsally in that region (see present Fig. 7A and B) corresponding to the "a much shorter dorsal pair, whose members are closely adjoining each other on midline" sensu Shiino (1956; Fig. 19A and $\mathrm{C}$ ).

When the posterior region of the trunk is examined using light microscopy, several processes are often seen in the same plane, obscuring their identity. When viewed using SEM, however, features of the distal margin or surface of the trunk become clearer, and anal processes or papillae-like structures become evident. The description of this area in new species must be approached with care, especially concerning the presence of caudal rami.

The presence of sensilla on the labium surface is observed only in the specimens of $P$. platensis n. sp. from fins base and not in those from nostrils. This feature seems to be relevant for the feeding activity of these copepods in their microhabitat. No previous reports have ever been made of this kind of setae at that position.

DNA barcoding (Hebert et al., 2003) analysis has demonstrated to be useful in free-livings copepods (Blanco-Bercial et al., 2011, 2014; Buckling et al., 1995). Also in species-level identifications of different taxa including crustaceans (Costa et al., 2007; Dippenaar et al., 2010; Morales-Serna et al., 2014) and used recently by González et al. (2016), for identification and description of a new species for the caligid Lepeophtheirus confusum González, Castro, Muñoz et López, 2016.

The morphological and the mtDNA-COI evidence allow to separate $P$. platensis n. sp. from P. exilis (with a genetic distance of 9\%). They are forming a clade, (both parasitizing mugilids), with a genetic distance of $12-16 \%$ from other Parabrachiella species here compared.

Avise (2000) and Waugh (2007) gave values of $1-2 \%$ for the intraspecific distance of mitochondrial genes and less than $10 \%$ of interspecific variation. In some cases, a lower genetic distance can differentiate species using the COI gene.

For caligids the level of genetic distance observed is bigger compared with other free living and parasitic copepods, González et al. (2016), report the level of genetic distance for Lepeophtheirus confusum range from 17 to $25 \%$ with other Lepeophtheirus species (based on COI). Morales-Serna et al. (2014) working with 11 Caligus species states the genetic distances among species ranging from 8.42 to $20.87 \%$. Oines and Heuch (2005) found distances of $18-20 \%$ among Caligus species.

For free living crustaceans, Costa et al. (2007) report genetic distances inside the same species of $4.92 \%$ in one crab genus to $31-39 \%$ in the amphipods. 

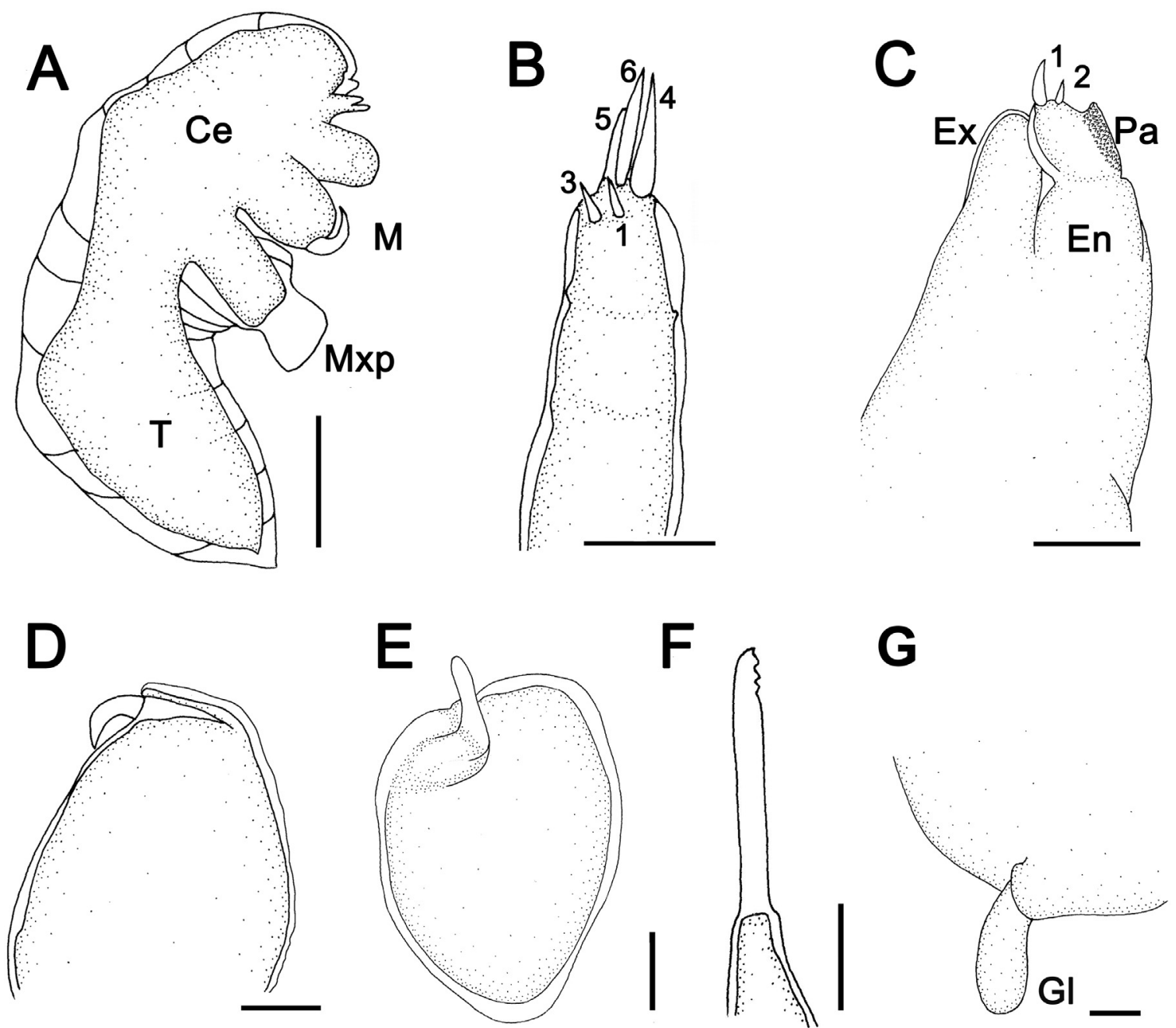

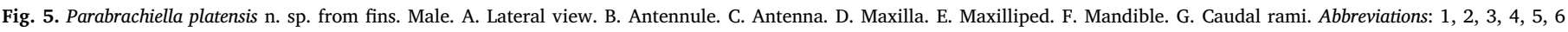

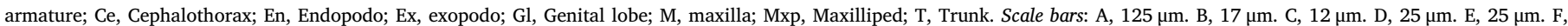
$13 \mu \mathrm{m}$. G, $13 \mu \mathrm{m}$.

Costa et al. (2014) found genetic distance of 6-16\% distinguishing three lineages in Acartia tonsa, previously known only by its morphology.

Castro-Romero et al. (2016) reported genetic distance among Pennellidae: Peniculus cf. fistula Nordmann, 1832 specimens from different host differ by $0.95 \%$, Metapeniculus antofagastiensis CastroRomero et Baeza-Kuroki, 1985 specimens $0.44 \%$, and for Trifur cf. tortuosus Wilson, 1917 2.25\%. By the other hand the genetic distance among $P$. cf. fistula and $M$. antofagastiensis is $17.86 \%$, and $P$. cf. fistula differing from $T$. cf. tortuosus by $18.16 \%$, these tree species of pennellidae genera well recognized and differentiated by its morphology.

Dippenaar et al. (2010) reported the use of COI in crustaceans to reveal possible cryptic species of symbiotic copepods Nessipus orientalis on elasmobranch. These authors found an average distance within the two clades $17.44 \%$ clearly a level expected for interspecific relationships. The genetic distance among different parasitic copepods can present a wide range of variation, in accord to their reproductive history, and evolutionary speed. Hebert et al. (2003), states that low genetic distance is due to short histories of reproductive isolations which need to be studied in each order, family, genus, and its species in order to have a wide picture of this aspect for the parasitic copepods on fishes.

At the moment Parabrachiella species that parasitize South American mugilids include $P$. exilis (on fins) in Chile and Peru, and P. platensis $\mathrm{n}$. sp. (in nostrils and fins), in Argentina. The exact identity of $P$. exilis for those specimens reported from Brazil by Knoff et al. (1994) must be tested using both morphology and molecular studies, they could belong to $P$. platensis $\mathrm{n}$. sp. based on the host species and morphology, but can not be affirmed without a morphological and molecular study of that copepod. This study disagree with Lebepe and Dippenaar (2016) who suggest only one species parasitizing Mugilids.

It is important to note that in species of medium to short size, like those reported here, the armature of the antennules or the antenna are sometimes hard to define, even at high magnification using optical microscopy. Also, it is necessary to use SEM to detect their real armature.

Summarizing, the new species is characterized by having two pairs of posterior processes on the posterior margin of the trunk, a papillae around the anal cavity, a lack of caudal rami, and near its base, and different to the secondary teeth reported for some species of the genus, the presence of at least 5 denticles in a row on the lateral surface of the maxilliped claw, near its base different to the secondary teeth reported for some species of Parabrachiella. In addition to describing a new species of Parabrachiella, the results obtained allow to report some features of its interspecific variation and also to know the DNA barcode for other two Parabrachiella ( $P$. exilis and $P$. kabatai) for which this genetic information was unknown until now. The presence on the same host of $P$. platensis $\mathrm{n}$. sp. on the fins and in the nasal cavities demonstrates a case of radiation into specialized microhabitats. 

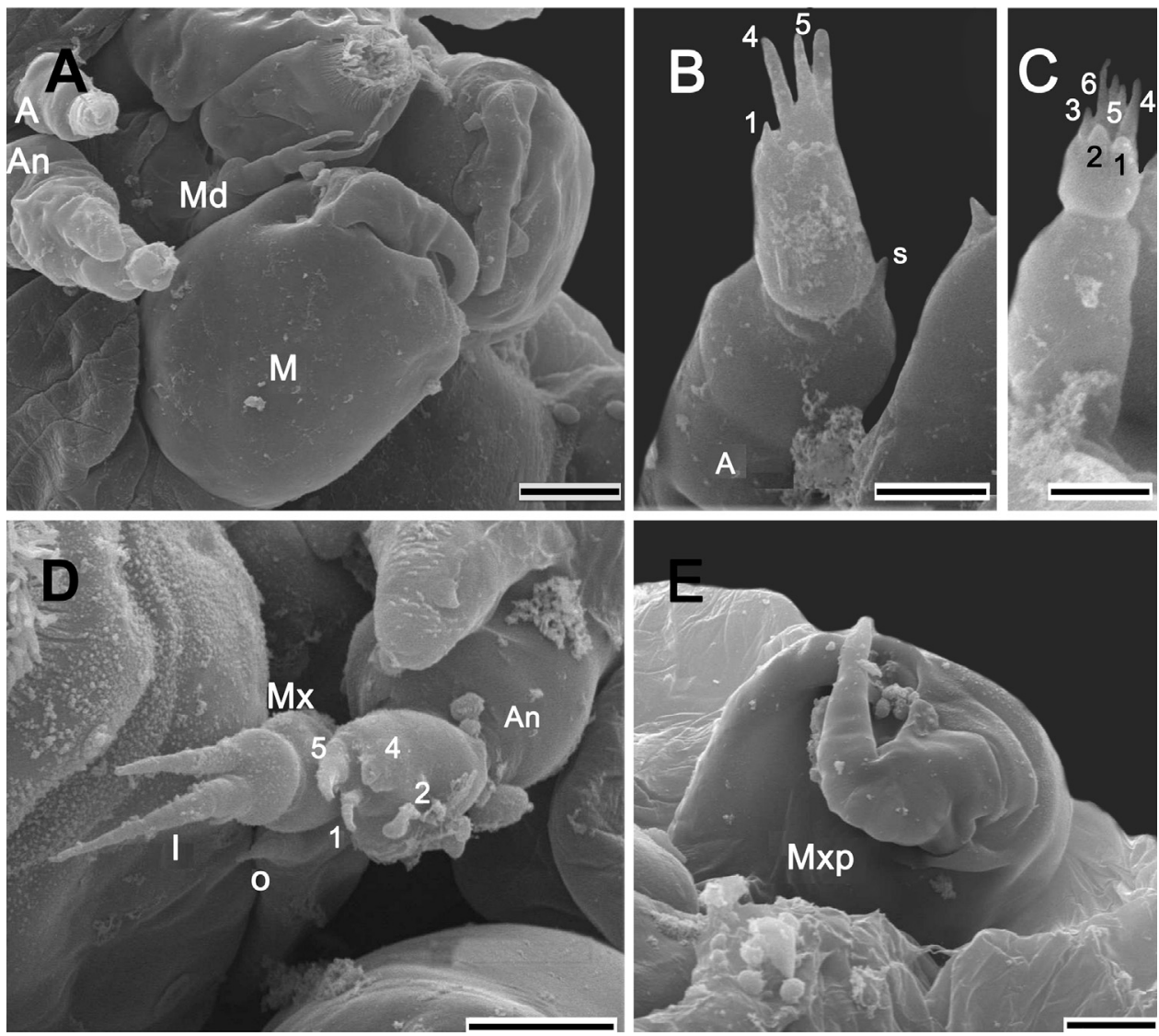

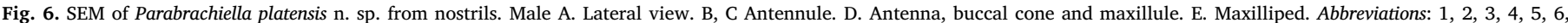
armature; A, antennules; An, antenna; I, inner lobe; M, maxilla; Mx, maxillule; Mxp, maxilliped; O, outer lobe; s, solus. Scale bar: A, C and E, $20 \mu \mathrm{m}$; B and D, $10 \mu \mathrm{m}$.
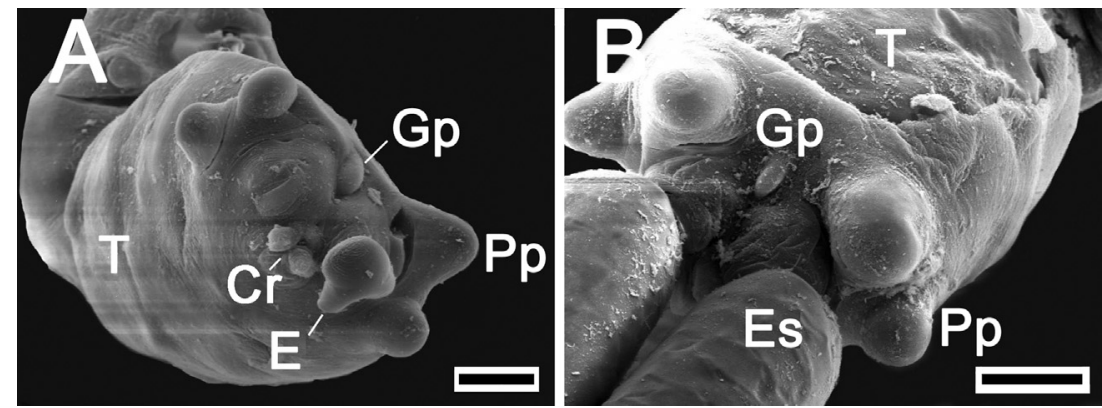

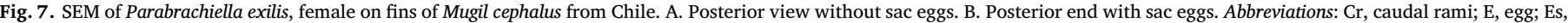
Egg sac; Gp, Genital process; Pp, Posterior process; T, Trunk. Scale bars: A, $100 \mu \mathrm{m}$; B, $200 \mu \mathrm{m}$.

Table 3

Genetic distance (expressed in percentage) among species of copepods. Abreviattions: Erg., Ergasilus; P. ani, Parabrachiella anisotremis; P. aur., Parabrachiella auriculata; P. exi., Parabrachiella exilis; P. hug., Parabrachiella hugu; P. kab., Parabrachiella kabatai; P. mer., Parabrachiella merlucci; P. pla., Parabrachiella platensis n. sp.

\begin{tabular}{lllllllll}
\hline & Erg. & P. aur. & P. ani. & P. kab. & P. pla. & P. mer. & P. exi. & P. hug \\
\hline Erg. & & 2 & 2 & 2 & 2 & 2 & 2 & 2 \\
P. aur. & 27 & & 1 & 2 & 2 & 2 & 2 & 2 \\
P. ani. & 28 & 13 & & 2 & 1 & 1 & 2 & 2 \\
P. kab. & 29 & 16 & 16 & & 1 & 2 & 1 & 2 \\
P. pla. & 27 & 16 & 12 & 12 & & 1 & 1 & 2 \\
P. mer. & 30 & 16 & 15 & 16 & 14 & & 2 & 2 \\
P. exi. & 27 & 17 & 14 & 12 & 9 & 15 & & 2 \\
P. hug. & 26 & 18 & 16 & 15 & 14 & 18 & 16 & \\
\hline
\end{tabular}

Table 4

Intraspecific genetic distances (expressed in percentage) in copepods. Abreviattions: Dist., Intraespecific genetic distance; Erg., Ergasilus; P. ani, Parabrachiella anisotremis; P. aur., Parabrachiella auriculata; P. exi., Parabrachiella exilis; P. hug., Parabrachiella hugu; P. kab., Parabrachiella kabatai; P. mer., Parabrachiella merlucci; n/c, not calculated, P. pla., Parabrachiella platensis n. sp.; Var., Variance.

\begin{tabular}{lll}
\hline & Dist. & Var. \\
\hline Erg. & $\mathrm{n} / \mathrm{c}$ & $\mathrm{n} / \mathrm{c}$ \\
P. aur. & 0.1 & 0.1 \\
P. ani. & 0.7 & 0.3 \\
P. kab. & 0.7 & 0.3 \\
P. pla. & 0.3 & 0.2 \\
P. mer. & $\mathrm{n} / \mathrm{c}$ & $\mathrm{n} / \mathrm{c}$ \\
P. exi. & 0.8 & 0.3 \\
P. hug. & $\mathrm{n} / \mathrm{c}$ & $\mathrm{n} / \mathrm{c}$ \\
\hline
\end{tabular}




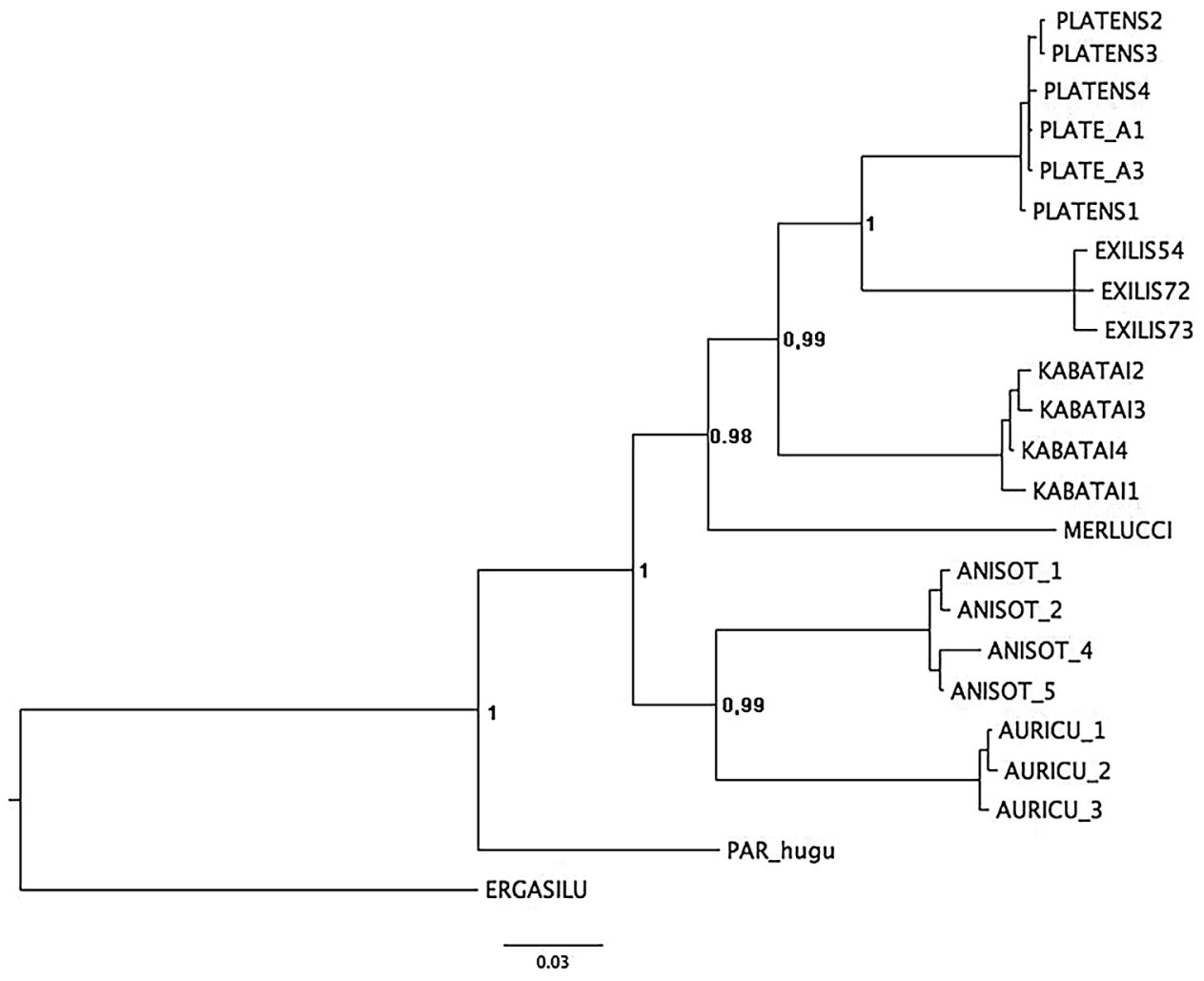

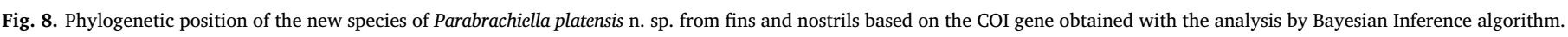

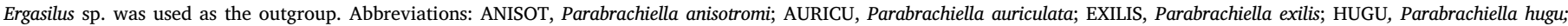

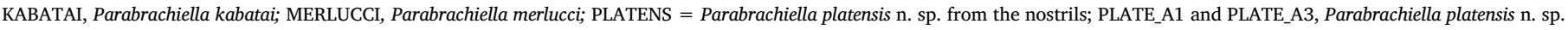
from the Fins.

New studies including more species of Parabrachiella could elucidate the real relationships among the genus species and especially for the case of $P$. hugu which appears as plesiomorphic to the species treated here.

\section{Acknowledgements}

The authors thank Joanna Browne from Griffith School of Environment and Australian Rivers Institute - Coast and Estuaries and Marine Invertebrates, Melbourne Museum, Australia and Philip Whitford from Biology Department Capital University Columbus, Cecilia Morgan and Sabrina Martorelli for useful advice in improving the manuscript. We also want to thanks Agustin Solari for providing samples of juvenile $M$. liza, Felicia Cardillo for helping in $P$. platensis n. sp. collection, Mariela Theiller (CINDECA) for taking SEM images, M. Marcia Montes for the preliminary draws, and Samanta Faiad (departament of "Ilustracion Cientifica" from the Facultad de Ciencias Naturales y Museo (FCNyM)) for the final draws. This work was partially funded by a research grant from the Agencia Nacional de Promoción Científica y Técnica (PICT 34412/05 and PID 0257) to S. R. Martorelli. Raul Castro wishes to express thanks to Universidad de Antofagasta where part of this research was carried out.

\section{References}

Alarcos, A.A., Etchegoin, J.A., 2010. Parasite assemblages of estuarine-dependent marine fishes from Mar Chiquita coastal lagoon (Buenos Aires Province, Argentina). Parasitol. Res. 107, 1083-1091.

Avise, J.C., 2000. Phylogeography: The History and Formation of Species. Havard University Press, London.

Blanco-Bercial, L., Bradford-Grieve, J., Bucklin, A., 2011. Molecular phylogeny of the Calanoid (Crustacea: Copepoda). Mol. Phylogenet. Evol. 59, 103-113.

Blanco-Bercial, L., Cornils, A., Copley, N., Bucklin, A., 2014. DNA barcoding of marine copepods: assessment of analytical approachs to species identifications. PLOS Curr Tree Life 1, 1-22.
Buckling, A., Frost, B.W., Kocher, T.D., 1995. Molecular systematic of six Calanus and three Metridia species (Calanoida: Copepoda). Mar. Biol. 121, 165-664.

Burns, J.M., Janzen, D.H., Hajibabaei, M., Hallwachs, W., Hebert, P.D.N., 2007. DNA barcodes of closely related (but morphologically and ecologically distinct) species of skipper butterflies (Hesperiidae) can differ by only one to three nucleotides. J. Lepidoptera Soc. 61 (3), 138-153.

Cantatore, D.M.P., Braicovich, P.E., Alarcos, A.J., Lanfranchi, A.L., Rossin, M.L., Vales, D.G., Timi, J.T., 2012. New records of parasitic copepods (Crustacea, Copepoda) from marine fishes in the Argentinean Sea. Acta Parasitol. 57, 83-89.

Castro Romero, R., Baeza Kuroki, H., 1987. Some species of Neobrachiella Kabata, 1979 (Copepoda: Lernaopodidae), parasitic on Chilean fishes, with description of Neobrachiella paralichthyos sp. nov. from Paralichthys adspersus (Steindachner). Crustaceana 51 (3), 245-253.

Castro Romero, R., Baeza Kuroki, H., 1987. Four new species of Neobrachiella (Copepoda: Lernaeopodidae) parasitic on Sciaena genus (Teleostei: Sciaenidae) in the South Pacific. Est. Ocean. 6, 1-24.

Castro-Romero, R., Montes, M.M., Martorelli, S., Sepulveda, D., Tapia, S., MartinesAquino, A., 2016. Integrative taxonomy of Peniculus, Metapeniculus, and Trifur (Siphonostomatoida: Pennellidae), copepod parasites of marine fishes from Chile: species delimitation analysis using DNA barcoding and morphological evidence. Syst. Biodivers. 14, 1-18.

Colautti, D.C., 1998. Sobre la utilización de trampas para peces en las lagunas pampásicas. Rev. Ictiol. 6, 17-23.

Costa, F.O., de Waard, J.R., Boutillier, J., Ratnasingham, S., Dooh, R.T., Hajibabaei, M., Hebert, P.D.N., 2007. Biological identifications through DNA barcodes: the case of the Crustacea. Can. J. Fish. Aquat. Sci. 64 (2), 272-295.

Costa, Bargoza, Silva Rodriguez, K.L.F., Marinho Costa, R., Vallinoto, M., Schneider, H., Sampaio, I., 2014. Genetic variability of Acartia tonsa (Crustacea: Copepoda) on the Brasilian coast. J. Plankton Res. 36, 1419-1422.

Dippenaar, S.M., Mathibela, R.B., Bloomer, P., 2010. Cytochrome oxidase I sequences reveal possible cryptic diversity in the cosmopolitan symbiotic copepod Nesippus orientalis Heller, 1868 (Pandaridae: Siphonostomatoida) on elasmobranch hosts from the KwaZulu-Natal coast of South Africa. Exp. Parasitol. 125 (1), 42-50.

Etchegoin, J.A., Timi, J.T., Lanfranchi, A.L., 2006. Redescription of Neobrachiella spinicephala (Ringuelet, 1945) parasitic on Pinguipes brasilianus Cuvier, 1829 from Argentina, with the first description of the male. Acta Parasitol. 51 (4), 290-293.

Folmer, O., Black, M., Hoeh, W., Lutz, R., Vrijenhoek, R., 1994. DNA primers for amplification of mitochondrial cytochrome c oxidase subunit I from diverse metazoan invertebrate. Mol. Mar. Biol. Biotechnol. 3, 294-299.

González, M.T., Castro, R., Muñoz, G., López, Z., 2016. Sea lice (Siphonostomatoida; Caligidae) diversity on littoral fishes from the south-eastern Pacific coast determined from morphology and molecular analysis, with description of a new species (Lepeophtheirus confusum). Parasitol. Int. 65 (6), 685-695. 
Hasegawa, M., Kishino, H., Yano, T., 1985. Dating of the human ape splitting by a molecular clock of mitochondrial DNA. J. Mol. Evol. 22, 160-174.

Hebert, P.D.N., Ratnesinghan, S., de Waard, J.R., 2003. Barcoding animal life cytochrome C. oxidase subunit (divergence among closely relates species. Proc. R. Soc. B Biol. Sci. 270 (Suppl. 1), S96-S99.

Hill, R.S., Allen, L.D., Bucklin, A., 2001. Multiplexed species-specific PCR protocol to discriminate four N. Atlantic Calanus species, with an mtDNA gene tree for ten Calanus species. Mar. Biol. 139 (2), 279-287.

Huys, R., Boxshall, G.A., 1991. Copepod Evolution. The Ray Society, London.

Ivanova, N.V., Grainger, C., 2006. Dye Terminator Sequencing of COI for the 3730 DNA Analyzer (Applied Biosystems). Protocols. Sequencing. CCDB Accessed 18 September 2013. http://ccdb.ca/docs/CCDB_Sequencing.pdf.

Ivanova, N.V., de Waard, J.R., Hebert, P.D.N., 2006a. An inexpensive, automation friendly protocol for recovering high-quality DNA. Mol. Ecol. Notes 6 (4), 998-1002.

Ivanova, N.V., de Waard, J.R., Hebert, P.D.N., 2006b. Glass Fiber Plate DNA Extraction Protocol: Manual Protocol Employing Centrifugation Protocol. Protocols. Sequencing CCDB. Available on line at: http://ccdb.ca/docs/CCDB_Advances_Methods_Release No1 Nov3rd 2006.pdf, Accessed 18 September 2013.

Kabata, Z., Raibaut, A., Ben Hassine, O.K., 1971. Eubrachiella mugilis sp. nov. un copepode parasite des muges de Tunisie 2. Bull. de l'Institut Nat. Scien. et Tech. d'Oceanogra, Peche de Salammbo, pp. 87-93.

Kabata, Z., 1979. Parasitic Copepoda of British Fishes. The Ray Society, London.

Katoh, K., Standley, D.M., 2013. MAFFT multiple sequence alignment software version 7: improvements in performance and usability. Mol. Biol. Evol. 30 (4), 772-780.

Knoff, M., Luque, J., Takemoto, R.M., 1994. Parasitic copepods on Mugil platanus Günther, (Osteichtyes, Mugilidae) from the coast of the state of Rio de Janeiro, Brazil. Rev. Bras. Parasitol. Vet. 3, 45-56.

Lanfear, R., Calcott, B., Ho, S.Y., Guindon, S., 2012. Partition Finder: combined selection of partitioning schemes and substitution models for phylogenetic analyses. Mol. Biol. Evol. 26 (6), 1695-1701.

Lebepe, M.C., Dippenaar, S.D., 2016. 2016. Bernard's Brachiella sp., Parabrachiella supplicans (Barnard, 1955) and Eubrachiella sublobulata (Barnard, 1955) (Copepoda: Siphonostomatoida: Lernaeopodidae) deposited in the Iziko South African Museum. Zootaxa 4061 (1), 1-51.

Morales-Serna, F.N., Pinacho-Pinacho, C.D., Gómez, S., Pérez-Ponce de León, G., 2014 Diversity of sea lice (Copepoda: Caligidae) parasitic on marine fishes with commercial and aquaculture importance in Chamela Bay, Pacific coast of Mexico by using morphology and DNA barcoding, With description of a new species of Caligus. Parasitol. Int. 63 (69), 79.

Oines, O., Heuch, P.A., 2005. Identification of sea louse species of the genus Caligus using mtDNA. J. Mar. Biol. Assoc. U.K. 85, 73-79.

Piasecki, W., Młynarczyk, M., Hayward, C.J., 2010. Parabrachiella jarai sp. nov. (Crustacea: Copepoda: Siphonostomatoida) parasitic on Sillago sihama (Actinopterygii: Perciformes: Sillaginidae). Exp. Parasitol. 125 (1), 55-62.

Posada, D. 2003. Using Modeltest and PAUP* to select a model of nucleotide substitution. In: Baxevanis, A.D., Davison, D.B., Page, R.D.M., Petsko, G.A., Stein, L.D., Stormo, G.D. (Eds.), Current Protocols in Bioinformatics. John Wiley \& Sons, New York, pp. 6.5.1-6.5.14.

Ronquist, F., Teslenko, M., van der Mark, P., Ayres, D.L., Darling, A., Höhna, S., Liu, L., Suchard, M.A., Huelsenbeck, J.P., 2012. MrBayes 3.2: efficient Bayesian phylogenetic inference and model choice across large model space. Syst. Biol. 61 (83), 539-542.

Sardella, N.H., Timi, J.T., 1995. Parasite communities of Merluccius hubbsi from the Argentinian-Uruguayan common fishing zone. Fish. Res. 27, 81-88.

Sardella, N.H., Etchegoin, J.A., Martorelli, S.R., 1995. Las comunidades parasitarias de Micropogonias furnieri (Corvina) en Argentina. Bol. Inst. Ocean. Venezuela, Univ. Oriente 34, 41-47.

Schwarz, G., 1978. Estimating the dimension of a model. Ann. Stat. 6, 461-464.

Shiino, 1956. Copepods parasitic on Japanese fishes, 12. Family Lernaeopodidae. Rep. Fac. Fish. Univer. Mie 2, 269-311.

Waugh, J., 2007. DNA barcoding in animal species: progress, potential and pitfalls. Bioessays 29 (2), 188-197. 